\title{
LEPROSY, DOMESTICITY, AND PATIENT PROTEST: THE SOCIAL CONTEXT OF A PATIENTS' RIGHTS MOVEMENT IN MID-CENTURY AMERICA
}

\author{
By Amy L. Fairchild
}

Columbia University

Historians typically regard the patient's rights movement as a product of a host of social and political changes in the 1960s, including the civil rights and other movements centered on individual rights. But in fact, the social context and broader political ideas of the 1940s and 1950s that gave rise to, shaped, and constrained the civil rights movement also influenced the patient experience. ${ }^{1}$ During this period, patients with leprosy confined at the United States Public Health Service (PHS) Hospital No. 66 in Carville, Louisiana twice challenged and changed the terms of their confinement. ${ }^{2}$ They did so at the apex of medical authority in America. ${ }^{3}$ Recounting the all but forgotten history of these events provides an opportunity for deepening our understanding of the far broader challenges to medical power and authority that would occur decades later.

Leprosy - a highly stigmatized disease that patients preferred to refer to by its more technical nomenclature, Hansen's disease, or, more cryptically, as "this package" or, in Cajun, as la maladie que tu nom pas (the disease you do not name) - ${ }^{4}$ affected only an estimated 1,500 to 5,000 people in the US. The patient census at Carville ranged between 200 and 400 individuals from the 1920 s through the 1960 s. ${ }^{5}$ On the surface, leprosy was a disease touching few, Carville a small and seemingly unimportant institution that stood apart from any broader story about America in the war and postwar period. But those confined created a community in which they articled their own version of American political, suburban, and domestic culture as they sought to gain control over the private sphere. A major societal change revolving around suburban domestic life was expressed in this unlikely setting controlled by science and the State. Through the lens of Carville, we can elaborate on the social and political changes that gave rise to and shaped patient resistance to scientific authority in an unlikely place and time.

I focus in this paper on the conflict between patients and hospital administrators over the organization and control of institutional life in the 1950s. But this analysis must be set against the backdrop of how the institution was organized and administered from the 1920s to the 1930s, which I describe in the first section of the paper. Carville stood at the crossroads of subjugation and freedom: despite the existence of institutionally unprecedented housing arrangements, because of the reality of compulsory confinement it was too hospital-like to be a home; despite its penal features, because of the unusual autonomy the patients enjoyed, it was too home-like to be a hospital. ${ }^{6}$

In the second section, I discuss the ways in which the therapeutic advances achieved during the 1940s prompted the PHS hospital administration to press for a stricter institutional culture and the ways in which broader societal changes enabled the patients not only to push back but also to build more of a private 
home life within the institution. This, then, sets the stage for the third section of the paper, where I analyze the PHS attempt to swing the pendulum decisively toward institutionalization in the 1950s. As it fought to reassert control over the patient population, it attacked the domestic life that patients had constructed within the confines of Carville. In this final, pitched battle, the private suburban home and the freedom from the State that it symbolized became the battleground for the struggle between patients and medical administrators.

\section{The Institutional Context: Carville in the 1920s and 1930s}

Like many "modern" sanitariums, the Carville leprosarium was constructed on a plan in which 12 patient dormitory buildings surrounded a nucleus of hospital, dining, and administration buildings, all overseen by a Medical Officer in Charge (MOC) and his staff of physicians, civil servants, and employees from local communities. ${ }^{7}$ This paternalistic, hierarchical, and quasi-military medical structure mirrored the broader medical culture; it also resonated particularly with the local culture in which the plantation continued to shape social relationships, creating stark power differentials between elites and their communities. $^{8}$

But despite the legacies of slavery and discrimination, this unique southern state gave a particular form to the experience of disease-based segregation. Even in the twentieth century, considerable racial mixture and Creole ancestrya product of early French and Spanish colonization and robust African slave culture-worked to conjoin blacks and whites to some extent; a remarkable host of ethnic cultures flourished, particularly in the southern region from New Orleans up through Carville and Baton Rouge. ${ }^{9}$ Although the state was predominantly white, it continued to have one of the largest foreign-born populations in the South, which would shape the experience at Carville.

The Carville population was up to 40 percent foreign-born — with most coming from Mexico, China, and the Philippines; two thirds of all patients were female. ${ }^{10}$ A little less than 10 percent of the patients were Black, and while the patient dormitories were racially segregated ${ }^{11}$ the school was not and patients proudly described a long history of institutional integration. Indeed, they claimed that "segregation was more or less discouraged." 12 For example, one African American man, Ernest Dennis, Jr., who came to Carville as a child in the 1940s, perhaps as late as 1950, explained that "I wasn't subjected to a lot of things that Negroes are subject to outside. But when I left for four years between ages 12 and 16, it was different. Then, I had to go to an all-colored school which was a change from the integrated school here." He continues on to describe experiences of discrimination that were completely foreign to him. After readmission to Carville, Ernest was elected as President of the Patients Federation. ${ }^{13}$

Less religious diversity prevailed at Carville. Three quarters of the patients were Catholic. While most of the rest were Protestant, there were always several Jews in the patient body. Social class did not necessarily shield individuals from confinement and so patients came from a variety of economic and social backgrounds. Unlike its counterpart on the remote island of Molokai in Hawaii, where leprosy was clearly viewed as a "tropical" disease and its carriers as "racial" 
others, those at Carville were always regarded as (and with rare exceptions were) American citizens. ${ }^{14}$

But if the need to isolate and stigmatize those with leprosy may have reflected racial assumptions that ran so deep that they remain impossible to analyze based on existing source materials, it also reflected both scientific and popular beliefs that the disease was highly communicable. Then, as now, leprosy's mode of transmission was something of a mystery, but it is currently understood to be a feebly communicable chronic bacterial infection typically acquired after prolonged childhood exposure in the roughly 10 percent of the population who are susceptible. Thus, while the children of those with leprosy were the most likely to become infected because of prolonged exposure during a period of heightened susceptibility, spouses were only rarely infected. If left untreated, the bacteria might invade an infected individual's peripheral nerves, skin, upper respiratory tract, and eyes over a period of years or decades. In some people, the disease manifested itself only as rose colored, insensitive patches of skin. In others, it resulted in blindness, disfiguring skin lesions, and deterioration of the bones and cartilage of fingers, toes, ears, and noses, creating the widespread misconception that leprosy caused pieces of the body to rot away and drop off. ${ }^{15}$

The authoritarian nature of medicine and public health combined with uncertainty about transmission as well as terrible, possibly racial but decidedly Biblical stigmas associated with the disease to reinforce a set of humiliating rules, established in 1921 when the PHS took over administration of the hospital. These rules stripped all inmates - regardless of race, religion, class, or status - of basic rights. ${ }^{16}$ Patients had no telephone. While there was a phone on the "other side" of the privet hedge separating the facilities of the medical personnel and staff, patients were prohibited from using it. If patients needed to make an emergency phone call, they either had to ask a favor of a staff member or abscond and hire an expensive taxi to take them to Baton Rouge and back-all at the risk of being caught and punished. In a state that had one of the most impressive highway systems in the nation by the end of Huey Long's administration in 1935, there was, by design, no paved road leading to Carville. While short vacations were permitted to 10 patients at any one time-a source of heartbreak at Christmas-they could only travel with the permission of the state health officers at their destinations and had to avoid all public transportation. ${ }^{17}$ Only patients from Texas, Louisiana, and Mississippi could travel home at all. ${ }^{18}$ Finally, though they were US citizens, as they were not necessarily considered local residents, the State of Louisiana denied them the vote.

There was no effective treatment for leprosy prior to the early 1940s and those confined could expect to spend decades of their lives in this federal institution. ${ }^{19}$ But for all its penal features and demeaning rules, Carville was not a "total" or "closed" institution. ${ }^{20}$ Although the facility was surrounded by a high barbed wire fence with a 24-hour guard, patients regularly "went through the hole in the fence" to hunt or for little jaunts into nearby Baton Rouge. Others simply escaped when they had had enough confinement or when they felt well enough to try making it on the outside. To be sure, the police would attempt to apprehend escapees, but it was a nearly impossible task given that almost no one provided the institution with his or her correct name or address upon admission. ${ }^{21}$ The staff fully expected and even encouraged such subterfuge given the great stigma 
attached to leprosy. ${ }^{22}$ While a few individuals had to be brought to Carville in handcuffs, most came "voluntarily" upon the threat that they would be reported (or the fact that they had been reported) to the health or police departments. Others came out of fear that they might "[infect] the whole city." ${ }^{3}$ Still others entered Carville when deformities caused by the disease could not longer be concealed ${ }^{24}$ Granting patients anonymity was a means of winning their trust and cooperation.

Isolation, as already noted, was not absolute. Patients were granted yearly leave if they came from selected nearby states and, although the facility was difficult to access, families and even friends could visit regularly. Particularly during the 1940s, as Carville received national publicity (almost exclusively thanks to the tireless efforts of the patients themselves to demystify leprosy), the institution became a kind of tourist attraction. Curious Americans from all over the nation paid visits to Carville and received patient-guided tours of the grounds, sometimes leading to the formation of fast friendships. They might attend a baseball game between the Carville team and one of the local leagues, a tournament on the patients' nine hole golf course, or even a dance-big events, often featuring a band from New Orleans. Such social events, organized with the assistance of family or friends, attracted not only patients but also staff and locals.

While each incoming patient was assigned a room in one of the men's or women's dormitories, as they made friends patients could negotiate for new placements. In some instances an entire dormitory building, which contained 12 private rooms and one communal bath on each floor, was occupied by mutual friends. ${ }^{25}$ Each "house" developed its own particular character over time, much like a sorority or fraternity. Some had a reputation for trouble-making, others for hospitality, still others for a particular ethnic membership.

A handful of patients abandoned the dormitories altogether. Reflecting the "self-built suburbs" phenomenon that began to characterize private housing construction, often on a mail-order basis, in the second and even third decades of the twentieth century, Carville patients constructed cottages at the back of the 361 acre property as early as the 1920 s. $^{26}$ Some were merely chicken coops, hunting lodges, or other types of shanties that patients had erected or converted, ostensibly with the permission of the MOC. ${ }^{27}$ Others were substantial structures. By the mid-1930s, motivated patients had built a dozen frame homes with hot and cold water, gas, electricity, and sewage. They sometimes purchased materials with their own money and sometimes just collected enough materials, like discarded sinks or toilets, by scrounging through the institution's dump. If the patient could make the connections, the PHS would donate the water, electricity, and gas. Some of these structures were suitable for year-round living, others for occupation only during the summer months or only as a retreat during the day. When they either became too infirm to reside in the cottages or left Carville after obtaining a medical discharge-achieved by running negative blood tests for the Hansen's bacillus for 12 consecutive months - those owning the cottages might rent or sell them to another patient.

The cottages completed the little community, which, by the 1920s, held within "its confines ... churches, shops, a theater, a morgue, the little cemetery, even a jail. Operating inside its fences [were] all the activities of a tiny city." ${ }^{28}$ The extent to which patients exerted autonomy in the organization of their personal 
and community lives was remarkable in an era of medical paternalism and deference to scientific authority. ${ }^{29}$

\section{Building Carville's Suburbs: Therapeutics and Social Transformation in the 1940s}

Prior to the early 1940s, the sole treatment for leprosy was Chaulmoogra oila foul smelling and largely ineffective tree extract that patients could opt to take either orally (at the price of extreme nausea) or by injection (at the risk of developing painful local abcesses). Just a year before the attack on Pearl Harbor, Dr. Guy Faget took command as MOC. Less of an administrator and more of a bench scientist than his predecessors, Faget brought Carville into a new era of therapeutic experimentation. First on his agenda were trials with diphtheria antitoxin. ${ }^{30}$ In 1941 and 1942, experiments with sulfa drugs began. In 1941, Faget also began trials with a new class of sulfones. ${ }^{31}$ The sulfones-first Promin and then Diasone-resulted in marked improvement in early cases within several months; within two to three years many patients were being discharged as bacteriologically negative. ${ }^{32}$

In a climate of medical triumph, Dr. Faget would begin to stress the importance of patient compliance in a series of articles, which appeared monthly from August 1942 to May 1943 in the patient newspaper: "The greatest cooperation of the patient with his physician is most conducive to a happy outcome.... [I]f he does not conscientiously follow medical advice and avoid conduct detrimental to his physical condition, he is obstructing his progress towards improvement." Indeed, the MOC cautioned, "'The surly bird catches the germ." "Thus, without imposing any hard and fast rules, Faget expressed a new desire to regiment the sleeping patterns, recreation, and meal consumption of patients_-all toward the end of arresting their disease in "the modern leprosarium." 33

The effort to extend medical control to meals carried particular significance. As one inmate observed, "There has always been an exaggerated interest in food in Carville. Many patients look[ed] no further ahead than the next meal. Once eaten, its merits or demerits [were] endlessly discussed until it [was] time for the next one." The cafeteria food had always been a source of bitter complaints amongst the patients, not only because of its quality but also because of the regimentation the dining schedule imposed on their lives. The institutional evening meal, for instance, was truly an early-bird special, served at 4:00. Since the late nineteenth century, people had begun to eat dinner later and later, particularly for meals viewed as entertainment. New Yorkers, for example, dined at around 7:00 — and that was early by national standards. ${ }^{34}$

Thus there was a long tradition of patients preparing their own meals in the dorms or cottages. The ability to eat later, "at a civilized hour," represented more than convenience or reprieve from culinary oppression. It gave patients who had every reason to expect that they might well never leave Carville a modicum of relief from institutional life: "For a little while every evening we almost forgot Hansen's bacillus." ${ }^{35}$ But meal preparation and consumption also had meanings firmly rooted in wider regional and national culture.

Despite its declining importance in the 1920s and 1930s, meal cooking had survived the age of mass production and consumption to remain "the central rit- 
ual of housekeeping" that took place in "the most important arena for women's creativity," the kitchen. ${ }^{36}$ For example, a Catholic girl of old French New Orleans stock who loved Mardi Gras, adored dancing, and eagerly anticipated her marriage to a medical student, Betty Martin's dreams were shattered in 1928 when she was admitted Carville at the age of 19. Alienated from the other patients during the early weeks of confinement, Betty initially took her cafeteria food and hurried away to eat it in seclusion. But Betty quickly learned that "The most important hour of any day was between five and six, when the majority of ladies and their 'boy friends' sat down to meals" that the woman "had probably struggled to prepare. Cooking in the rooms was grudgingly tolerated, but nothing could discourage the cooks. Nearly everyone wanted to fix something special for supper," and with a cheap electric hot plate easily accessible from the Sears Roebuck catalogue one would quickly "[learn] the art of 'Carville cookery.' "37

In some respects, cooking and dining at Carville retained nineteenth century traditions. Meals also reflected the persistence of regional dining cuisines and cultures, limited as their preparation might have been by the hotplate. New Orleans, with is French, Creole, and Cajun cooking traditions, had not succumbed to the national trend toward lighter, simpler, less savory, but more convenient fare that was beginning to characterize national eating patterns. For the many men and women confined in Carville at the prime of their youth - the time in which Hansen's disease typically became manifest - the preparation and consumption of food at Carville represented a means of creating and sustaining a sense of solidarity and social life. ${ }^{38}$

Faget, however, did not prohibit the independent cooking that was pervasive at Carville. Indeed, his administration, like those before it, implicitly supported the practice. Patients who had jobs within the institution or who simply had the money might purchase food items from the patient owned and operated canteen. The PHS allowed patients to grow gardens-commonplace at Carville both for the meal supplementation and sociality they offered. ${ }^{39}$ Further, the PHS itself issued "raw rations" of flour, milk, eggs, meat, and other basic food supplies to any who requested them. But if Faget did not deny them the right to prepare their own meals, he persistently sought to dissuade them from doing so. He explained that nutrition "ranks high in the treatment of Hansen's disease." [Emphasis added.] Meal preparation was a "science" best left to trained experts "to supervise in every modern hospital." ${ }^{\text {" }}$ The patient's role, Faget advised, was to refrain from supplementing cafeteria food and to "learn to eat of everything that is served." 41

There was a time when patients did not balk even at harsher efforts to alter their private rituals. In 1935, for example, a new MOC forbade males from entering females' rooms. His goal was to bring an end to sexual liaisons, but, more visibly, he disrupted the practice of private couples dining. In the context of the Depression, however, notions of society's obligations to the dependent shaped the patient response. While the "leper" who resisted confinement might be regarded as criminal, those who accepted confinement for the sake of the public's health fulfilled their duty as citizens. In return for fulfilling this obligation, Carville offered its inmates absolute security. Shelter, food, clothing, and medical care were guaranteed to all patients by the State, regardless of race or social class. The medical paternalism that prevailed at Carville was consistent 
with a broader vision of the universal rights of citizens as they were formulated from the Progressive era through the years of the Depression and into the New Deal. Deep-rooted sensibilities about what the rights of citizenship meant, then, gave patients a sense of entitlement to having food provided for them, but not necessarily to cooking it for themselves. Without complaint, the Carville population readily and creatively accommodated themselves to the situation in the 1930s: "The traditional candlelight suppers à deux in the woman's room had to be modified to meet a new order, but they were not given up. The card table was merely dragged into the open doorway, the man seated in the hallway outside the room, and the woman opposite him, inside the room where she had access to the hot plate and larder." ${ }^{42}$ (The birth rate, incidentally, shot up.)

But in the war-time context, the response of patients would be shaped by the therapeutic advances as well as new social and political values. While the sulfones initially heightened the patients' sense of reaping the benefits of a paternalistic Welfare State that provided for the needs of the most vulnerable, patients' hope for recovery also interacted with changing notions of the rights and obligations of citizenship, deepening a sense of autonomy and instilling a new willingness to challenge and critique. The war witnessed the beginnings of what George Lipsitz calls "a fundamental revolution in economic, social, and cultural life." ${ }^{43}$ A new articulation of the idea of freedom was the thread tying these transformations together. ${ }^{44}$ In 1941, President Franklin Delano Roosevelt helped to give prominence to civil rights in his articulation of four "essential human freedoms:" freedom of speech, freedom of worship, freedom from want, and freedom from fear. ${ }^{45}$ If American business argued that free enterprise represented a fifth essential freedom, another candidate in the mind of this president paralyzed by polio might have been freedom from disease. ${ }^{46}$ The essential point is that while some of "Four Freedoms" played on older Depression-era themes of freedom from want and freedom from fear, others began to promote increasing attention to fundamental civil rights. ${ }^{47}$ The changing atmosphere helped to inspire the civil rights movement as racial segregation and discrimination became increasingly difficult to justify in a nation battling Nazi tyranny and racism; ${ }^{48}$ it also brought to an end patient tolerance for the long-prevailing conditions at Carville.

Underscoring the importance of the intersection of therapeutic and social change, patients explained that the new therapy "meant living to many-not so much from a life or death point of view, but rather 'Master of My Fate Living., "49 A sense of outrage began to replace that of privilege and gratitude: patients saw a right to exert a degree of control over their care and their general treatment within Carville. In the early days of sulfone therapy, for example, Betty Martin would write "Only in American could a hospital like this be found, where we sick are treated by our government, not as the least among men, but as the best." ${ }^{50}$ But as they began to feel better and consider the possibility of a medical discharge, patients began deeply to resent that they were "still being treated very much like inmates of a penal institution. ${ }^{"}{ }^{1}$ Carville was rapidly morphing from hospital to prison in the eyes of the patients.

By the winter of 1942, Faget-feeling the increase in confidence and autonomy amongst his medical charges-complained of "a tendency for [the patient] to become too sure of himself. After years of hospitalization he may feel that he 
knows as much about his condition as the doctor does." New patients should be on guard against "old-timers," Faget warned, and refuse "to be influenced by them, led astray.... " Living a "normal life" under PHS authority did not prevent patients from "indulging" in recreation and activities, reading and going to movies, cooking their own meals. But it did require always limiting activities in accordance with medical advice. In Faget's conception of care, then, the patient subjected himself or herself completely to the authority of medicine. As a signal of exactly who was in charge at Carville, Faget reminded patients of the 11 official PHS Rules and Regulations promulgated when the PHS first took control of the hospital in 1921. These rules, said Faget, were still in effect and patients would be wise to familiarize themselves with them. ${ }^{52}$

This time, it was activism rather than accommodation that characterized the patient response. Faget, in attempting to shore up medical hegemony, "stirred up a veritable hornet's nest" amongst the Carville population, who in turn sought to circumscribe the medical sphere of authority within the institution, to push the pendulum toward Carville as home. They saw little of value in any of the rules- "replete with such words and phrases as quarantine, apprehension, detention, isolation or restraint" - and immediately began demanding that the PHS revise or revoke the lot. But those confined focused their challenge on the rule that most defined the Carville social and domestic order as being under the control of medicine: "Patients shall on no account visit the quarters of patients of the opposite sex without permission of the medical officer in charge. Visiting between patients of the opposite sex shall be permitted in the appointed visiting place only at such hours as may be set aside for that purpose." ${ }^{\prime 53}$ It was not simply the case that patients wished to have this rule revoked: they upped the ante and vehemently demanded official housing for married couples.

Although it had a history dating back at least to the $1890 \mathrm{~s},{ }^{54}$ the suburban home and home life stood at the center of the wartime transformation in notions of freedom; it was during this period that dreams of homeownership appeared achievable for all Americans. ${ }^{55}$ Thus, Eric Foner explains that "Even more than in the past, homeownership became an American creed." ${ }^{56}$ The home, particularly the suburban home, represented the promise of egalitarianism and democracy within the broader society. ${ }^{57}$ It represented domestic living, privacy, and independence. This social transformation also gripped the Carville patient population, who likewise wished to be treated and regarded as resident citizens, not merely as dependent "patients." They sought the right to create a "traditional" suburban space within an institution: they sought a space where the PHS had no authority, no control. ${ }^{58}$

The patients' focus on the dozen or so married couples who lived at Carville did not mean that single adults were excluded. The leader of the movement for married couple housing was, after all, Stanley Stein. Stanley—a confirmed bachelor whose editorials in The Star, the widely-read Carville patient newspaper, eventually helped to spark a curious romance with Tallulah Bankhead—owned a cottage and, indeed, suggested that he lived with a female patient (who left him for another after Stanley repeatedly rejected her proposals of matrimony). Many single patients maintained intimate relationships at Carville and owned many of the private cottages. Even married patients with spouses on the outside were often coupled with other patients, single or married. So, if food was one 
of the preoccupations at Carville, sex was the other. Remarkably, all sexual relationships were tolerated even by the most conservative of the patient body. Betty Martin, for example, was initially repelled by the idea of going on an unchaperoned date, much less sex out of wedlock or even sex for any purpose other than procreation. But, with time, this devout Catholic became deeply sympathetic: "segregation was responsible for evils and temptations which those not penned together and bearing a common stigma can ever know." ${ }^{159}$ Unusual hardship merited acceptance of unusual domestic rights.

Reflecting both enthusiasm for the housing boom and a profound desire to attain her own freedom, Betty Martin penned a poem from her dorm room in Carville entitled "Yearning." It captured her dream of home ownership with her husband Harry, who lived in a men's dormitory. Its recurring line invoked her longing for "A place to call my very own." First published in The Star in 1945, before the year's end it was reprinted in newspapers, college bulletins, and religious pamphlets across the country, drawing national attention to Carville and an avalanche of letters from well-wishers to Betty, whose message had truly "hit home." Betty spoke to her desire for her release so that she and Harry might acquire the home of their dreams, but she also expressed a widely-shared desire for domestic privacy. The patients' goal was "to get the 'institution' out of" Carville. As one patient who owned a cottage explained to the MOC, the infirmary "is the hospital but out there (pointing to the patients' cottages) is our home." 60

Residents thus strengthened and, indeed, invested with new meaning preexisting boundaries between home and hospital, individual and community lives and institutional routine. As Americans fought to free other nations from oppression and as information and propaganda regarding Japanese prison camps and Nazi concentration camps began to accumulate, more and more veterans who had fought in the Pacific, where leprosy was endemic, were confined at Carville. ${ }^{61}$ Thus, the Carville population began to see itself as not just one that served society by taking extreme measures to prevent the spread of a disease; it increasingly viewed itself as a population that had risked life and limb for the liberty of others and deserved the same rewards. ${ }^{62}$ Understanding that veterans were regarded as deserving of "every consideration," and motivated by the same set of circumstances that spurred Blacks who had served in the military to bristle anew at racial segregation, discrimination, and violence upon return to American society, patients skillfully used stories of those who had served in World War II only to find themselves "imprisoned" at Carville to underscore the injustices of compulsory isolation. ${ }^{63}$

At Carville, the attack on confinement would dovetail with the suburban domestic ideal, underscoring the extent to which the kitchen-centered suburban home provided a space for the political and cultural spheres to merge. Gertrude Hornbostel, who had come to Carville in 1946 under her own name amidst great national publicity as her military husband fought unsuccessfully for the right to live in the institution with her, cited meals and privacy — central domestic rights-as key losses that she faced upon confinement. Although not a veteran, she had accompanied her husband to the Philippines, was taken prisoner there, and was held for nearly three years in a Japanese concentration camp where she had only narrowly escaped execution. Was she, who had endured so much, truly expected to be grateful for "Standing in line for your food and hav- 
ing it slapped on your tray so that you can carry it off on your shirt front? Or using the same bathroom facilities with the 13 other patients that live in your house." 64 Thus, the patient challenge to the institution, which reached a national audience, began to coalesce around the home in general and the kitchen in particular, mirroring the growing prominence of the political dimensions of suburban domesticity as a powerful democratic ideal. ${ }^{65}$

Carville patients shifted their focus from the dormitory rooms-the outfitting and decoration of which had occupied attention from the Depression through the war years-to the patient-constructed cottages ${ }^{66}$ the number of which would double between the mid-1940s and mid-1950s. ${ }^{67}$ In "Cottage Grove," Anglo, Chinese, Mexican, and Filipino home owners lived as neighbors. Some of the cottage owners were single, but most were married. It was after his marriage to another patient-resident in 1948, for example, that Johnny Harmon, despite quite limited finances, determined that he must build a home of his own to make "life more complete" and "normal." The image of their dwelling that he preserved in his self-published memoir featured his wife in the kitchen. (Figures 1 and 2.) Thus, the home, in general, and the ability to cook and dine at leisure, in particular, began to represent not simply a fleeting escape from the monotony of confinement, but attainment of "normal living." 68

The patients referred explicitly, though certainly with a touch of poignant irony, to the cottages as being in "the suburbs." ${ }^{69}$ Invariably, as a means of underscoring the suburban domestic ideal (but also decidedly distinguishing it from a broader American norm of meals "covered with mayonnaise and whipped cream" that were "so white, and so creamy [they] might have been planned at a

\section{Figure 1}

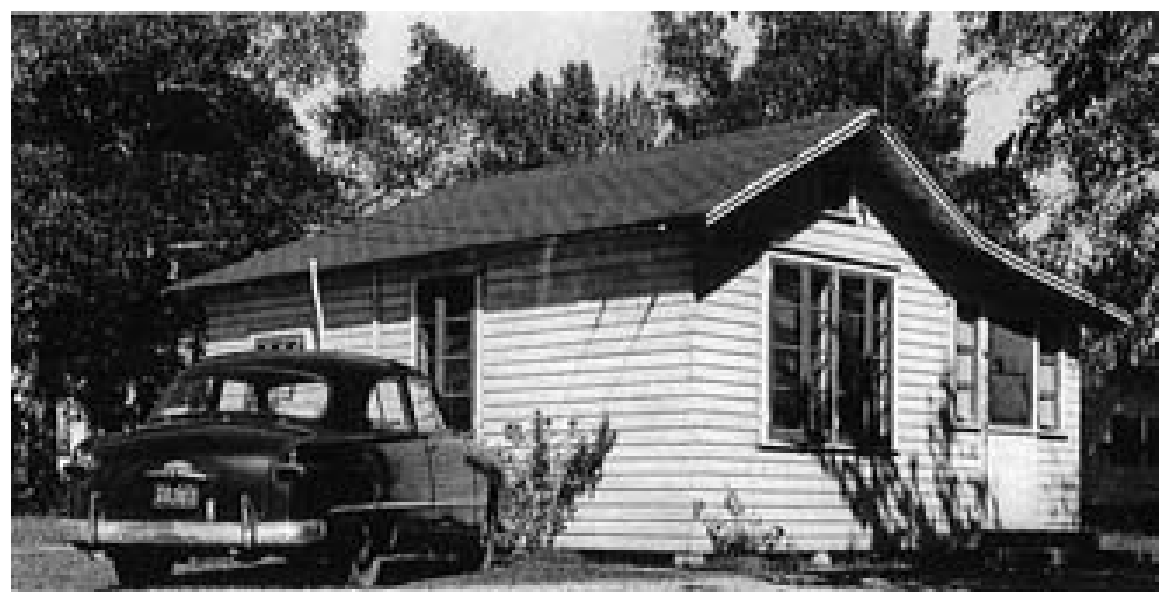

Johnny Harmon used an old storage shed, purchased from another patient for $\$ 100$, as the basis for his home. Some of the materials he purchased, others, like windows, doors, a tub, and sinks, he salvaged from the institution's junk pile. He invested a total of $\$ 1,800$ in the structure. Source: Johnny Harmon, King of the Microbes (2000). Courtesy of Anne Harmon Brett and Johnny C. Harmon. 
Figure 2

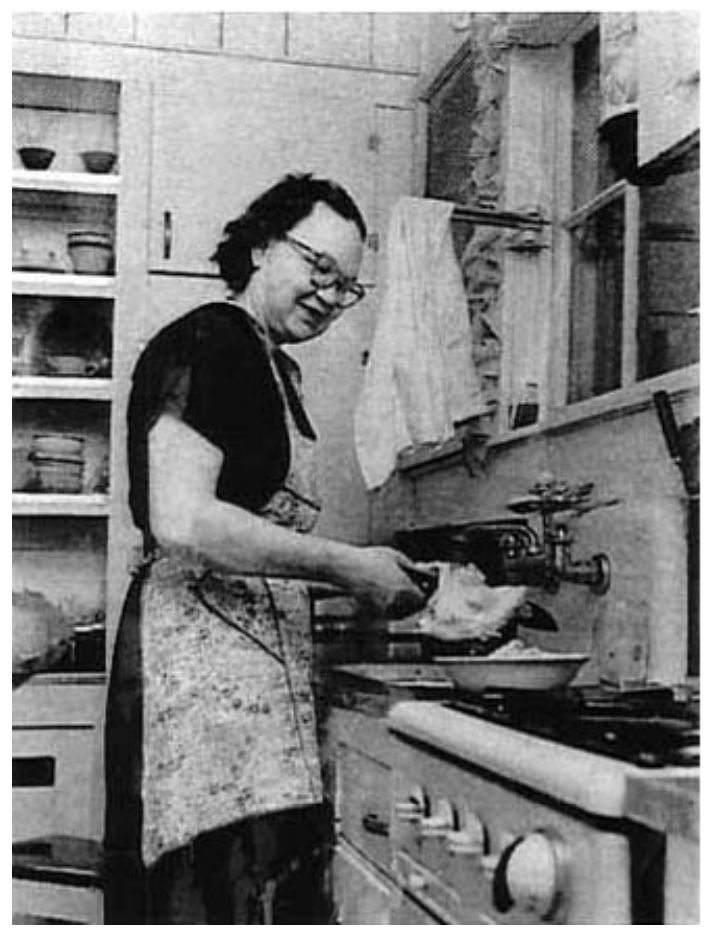

Anne, Johnny Harmon's wife, is here pictured in their Carville kitchen. Source: Johnny Harmon, King of the Microbes (2000). Courtesy of Anne Harmon Brett and Johnny C. Harmon.

cooking school"), residents described the decidedly "coarse" ethnic delights of someone's "real Italian spaghetti" or the smells that "fill the air with the pleasant scent of herbs and spices unheard of in any of the hospitals kitchens." Descriptions of "home life" were replete with references not just to cooking, but to a sort of gourmet cooking that, even if it came off of a hot plate, did not come out of a can (unless it was the patients themselves who had done the canning). ${ }^{70}$ Whatever the reality of segregation, patients promoted a pluralistic, democratic, egalitarian vision of the suburban community at Carville.

\section{The Carville Kitchen: "One of the touchiest subjects"}

Given their interests in veterans, particularly those confined in Carville, one of the long-time supporters of the entire patient population at the institution was the Louisiana chapter of the American Legion. Indeed, they had established a Legion post at Carville and a number of patients were members. Watson B. Miller, once the Legion's National Rehabilitation Director who had taken a personal interest in many of the Carville veterans, was now head of the Fed- 
eral Security Agency (FSA), which, at that time, housed the PHS. The Legionnaires used their 1945 National Convention to propose that the Surgeon General appoint an Advisory Committee on Leprosy. They used their influence within the FSA to achieve this and ensure that the organization would take seriously Carville patient proposals for change. The patients were happy to oblige and developed 15 recommendations for the committee to consider. ${ }^{71}$

In 1946, the committee overwhelmingly and enthusiastically endorsed all of the changes that the patients requested; but it lacked the power to do anything but advise the Surgeon General. ${ }^{72}$ The most radical of the patient demands, ending compulsory confinement and providing for outpatient treatment, would require not only federal action and funding but also legislation on the part of most states, each of which had its own isolation laws for communicable diseases. Other demands, like housing for married couples, required federal funding. But others, such as liberalizing enforcement of the PHS rules and regulations, might be more readily attainable if the PHS were amenable. ${ }^{73}$

And, indeed, a new hospital administration moved swiftly to make Carville "as much like a natural community as possible and to eliminate all unnecessary functions of an institutional character." 74 The new MOC, Dr. Frederick Johansen, had been responsible for the day to day treatment of patients since 1924. Like the other PHS officers stationed at Carville, he lived on the grounds and, despite the segregation of living quarters, was very much a part of the community. Johansen did not hesitate to give his charges, whom he viewed as friends and neighbors, greater means to travel and communicate with family, associates, and others on the outside. The barbed wire atop the fence enclosing Carville was removed and the road to the institution paved, and it was during this period that the state of Louisiana granted patients the vote. ${ }^{75}$

But the first set of patient demands emerged during or immediately after the Second World War. As the Cold War, in general, and the spirit of intolerance epitomized by the inquiries of the House Un-American Activities Committee (HUAC) and Senator Joseph McCarthy, in particular, began to grip national and domestic politics, the space for protest and dissent would become decidedly more cramped. Patient demands had fallen on highly receptive and sympathetic ears. The progressive if incremental changes at Carville were largely discretionary on the part of Johansen; the federal rules governing patient conduct in Carville remained unchanged - they were simply ignored. In short, the hierarchical authority of the PHS remained firmly intact. Indeed, it was precisely such authority that allowed a benevolent response on the part of the MOC. While recognizing that "during the present regime the medical aspect rather than the penal is now being stressed," Carville residents understood that, unless revised or revoked, the federal rules could "be twisted to meet the particular whims of the MOC who may be in charge, in whom, like other rules, it invests absolute authority." ${ }^{\prime 6}$

The residents were prescient, and in 1953 the community found its rights under siege when Carville's beloved "Dr. Jo" reached the age of mandatory retirement. The 65 -year-old father figure was replaced by Dr. Edward M. Gordon, a native of Louisiana who felt bound by a sense of science and what it dictated as well as the supremacy of medical authority. ${ }^{77}$ While the patients and much of the medical community, like the former MOC, strongly believed that isolation 
was not the appropriate strategy for controlling leprosy given the infrequency with which it was transmitted, medical opinion was divided. Others felt that the uncertainty regarding disease transmission warranted continuation of isolation and, indeed, a new severity in enforcing it. ${ }^{78}$ As they played out in Carville, the public health and medical debates about whether to relax or tighten isolation for leprosy stood in eerie parallel to the mounting resistance to racial integration on the part of southern states in the wake of the 1954 Supreme Court decision in Brown v Board of Education. But if the "Southern Manifesto" represented a political commitment on the part of a coalition of southern states to resist Black integration by "any lawful means," ${ }^{79}$ within the realm of science and medicine outright coercion would be somewhat tempered by persuasion.

In an attempt to minimize casual contact between the infected and healthy, the new MOC "advised" hospital staff and officers to cease fraternizing with patients. But while there could be some discretion regarding casual contact on the part of those paid to work with the infected, there would be less tolerance for such contact with the general population. The regular baseball games between patients and local teams that had for decades drawn spectators from the region were quickly brought to an end. Further, Gordon prohibited dancing between patients and non-patients, even married couples, at the weekend dances held at Carville. ${ }^{80}$

Gordon thus sought to purify the institution and place policy on a scientific footing: to remove individuals who were not "patients," to segregate more strictly those who remained, and to restore institutional order and medical authority - that is, put patients in their place. The civilian hospital personnel, who received "hazard pay" for working at Carville and who had long feared losing the salary bonus if the disease was not perceived to be highly contagious, enthusiastically supported Gordon. Picking up on Gordon's cues, they circulated a petition asking, "'Do you want the patients to run the hospital instead of the doctors?" 81 In short, there was no question in Gordon's mind that Carville was a hospital and not a home.

Gordon immediately and forcibly discharged all able-bodied "cases" who had run negative test results for 12 months or longer; he invited the partially and permanently disabled who were negative to leave. (Such cases were typically, and ironically, referred to as clinically "arrested." Sulfone therapy did not represent a cure for leprosy. A patient might run negative tests for several years and then reactivate.) Many of these individuals had been at Carville for a decade or longer and often had not maintained contact with their families. For example, long-time patient and Star co-editor Ann Page's first husband had divorced her after she was diagnosed with leprosy and sent to Carville. Hers was a familiar story. Family members frequently severed all ties with Carville exiles, leaving even children to wonder what had happened to a parent. In other cases, "lives had become 'institutionalized." "82

Gordon further attacked what Alice Kessler-Harris describes as "economic citizenship," which emphasized the right to work. ${ }^{83}$ Even those who did not face mandatory discharge found themselves threatened within Carville: many were let go from their part-time hospital-based jobs and replaced by civil servants or locals. ${ }^{84}$ Gordon compounded this injury when, in 1955, he announced that husbands and wives could not both hold jobs within the institution. 
The Carville family was based on an equality of the sexes that had roots in leprosy as a disease as well as in working and middle class life. ${ }^{85}$ All of the married couples within Carville had met and wed while institutionalized ${ }^{86}$ Each partner in the couple understood the stigma of leprosy and entered their unions with a particular sense of commonality. "It was wonderful to be with someone loved who shared one's secret," explained Betty Martin. "There was no watching against slips of the tongue or being hurt and wondering just what had been meant by some careless remark." 87 Reflecting this equality, while Carville residents as a whole earned less than citizens from nearby communities for doing the same jobs, all of those confined received equal pay for equal work regardless of gender. ${ }^{88}$

Elaine Tyler May argues that Depression - the era in which many of the couples were originally sent to Carville-and world war "laid the foundations for a commitment to a stable home life, but they also opened the way for a radical restructuring of the family." ${ }^{89}$ May asserts that the Depression made possible "a new type of family based on shared breadwinning and equality of the sexes" in addition to a more traditional model based on distinct sex roles in which the father was the wage earner. ${ }^{90}$

On the one hand, we can read Carville-a semi-closed institution—as allowing an alternative model of the family that differed from the prevailing middle class norm of working father and stay-at-home housewife to persist into the 1950s. ${ }^{91}$ For example, Betty Martin explained that while she and Harry always read papers and followed US and world events, Carville kept had them in a world apart: "The youngsters with whom we had shared the era of jazz were now middle-aged citizens with homes and growing children. They had advanced normally through two decades that had seen many changes, including a world war. Harry and I had stood still during those years, like enchanted people." ${ }^{\prime 2}$

But, on the other hand, we can also see in Carville reflections of the story about American families, both middle and working class. ${ }^{93}$ While provided with food, shelter, and clothing, ${ }^{94}$ most if not all partners in Carville marriages tended to work as patient orderlies, laboratory technicians or assistants, dormitory attendants (janitors), or in some other semi-skilled, caring, or laboring position. ${ }^{95}$ In order to save any money in the event of discharge, both men and women had to work. Therefore, it took both partners to build up even very modest savings. Betty and Harry, for example, accumulated $\$ 7,000$ in savings and war bonds during their two decades within Carville, which also included what they had earned in four years on the lamb, when they lived first with their families and then together after their marriage while they worked in New Orleans. ${ }^{96}$ Any children that couples bore while at Carville had to be cared for outside of the institution: no one under the age of 20 was allowed onto institutional grounds unless infected. ${ }^{97}$ Parents, while they did their best to provide financial assistance, had to rely on family, friends, or other caregivers to raise their children. Therefore, those couples (and singles) who did have unplanned children worked to pay for their care on the outside. ${ }^{98}$

Within Carville's homes, men and women also shared domestic tasks. Major Hans Hornbostel, a World War II veteran and survivor of the Bataan death march, had accompanied his wife Gertrude to Louisiana when she was diagnosed with leprosy and confined. Although he was formally allowed to remain within 
the institution only during visiting hours (each evening he exited through the main gates only to come back in through the "hole in the fence" and then secret himself out again at dawn), the military couple purchased a small cottage on the hospital grounds. Gertrude explained that husband Hans "does most of the housecleaning, dishwashing and other odd jobs.... He does quite a bit of the cooking too...." The Hornbostels were hardly the only couples who defied conventional norms. A cartoon that ran in The Star pictured a husband and wife sitting together, both knitting. The artist commented that "Some of us had strange hobbies. My friend Louis Bodreaux baked the most delicious cakes," underscoring the extent to which individuals at Carville understood expected gender roles. Because leprosy left individuals with different levels of disability, if a couple wanted a private home, the man often simply had no choice but to cook, clean, and perform other domestic chores. ${ }^{99}$

Gordon's prohibitions on the two-family income thus cut to the very core of the marital egalitarianism and economic citizenship that had taken strong hold at Carville. ${ }^{100}$ Gordon threatened to strike further at Carville marriages when he determined that the patient-constructed facilities were government propertya matter of much concern among the residents even before Gordon's intentions became evident. The cottages not only provided domestic privacy but also represented the rewards of economic citizenship. Residents had either paid for the cottages to be built or purchased them from the original builders. Further, they had added wiring, plumbing, and all appliances and furnishings at their own expense. The cottages were the residents' primary if not sole investment. ${ }^{101}$ They were also central to the physical wellbeing of some. For example, Stanley Stein argued that if he were to lose his cottage he would have to give up the convenience of paying a patient orderly and go live in one of the "blind dormitories," where a dozen or more visually impaired individuals were cared for by a single attendant.

In 1956, apparently resolving not only the question of who owned the cottages but also what constituted appropriate living accommodations for both single individuals and married couples, the United States House of Representatives appropriated $\$ 25,000$ to purchase the homes from the patients. ${ }^{102}$ As part of this federal compensation plan, patients understood that their cottages, once taken over by the government, would be thoroughly renovated and that each couple or individual would eventually return. Evoking World War II or perhaps even Cold War imagery, the residents declared that news of the Gordon administration's decision to raze the cottages, move all the couples into kitchenless apartments, eliminate the distribution of "raw rations" for those who wished to cook for themselves, and ban cooking at the institution altogether "fell like a bomb."103

Gordon, taking his cues from the larger culture in which both the efficiency of the modern kitchen was promoted as reducing the workload of housewives and eating out was becoming a family affair often instigated by women, reasoned that certainly women would not mind being relieved of the burden of cooking. ${ }^{104} \mathrm{~A}$ PHS information officer combined this rationale with the familiar medical one: "Food is an important part of the therapy of this disease, and I want the diet supervised. I feel we can feed you better in the dining room."105

While the assaults on Carville residents were many and residents would protest all of the policy changes, the community focused its resistance on the PHS 
attempt to eliminate the kitchens, which lay at the heart of a conception of what we might call "domestic" citizenship and the achievement of "everyday" rights that made Carville livable on a day-to-day basis: the freedom to make decisions about when to eat, what to eat, what to wear, which movies to watch, where to live. ${ }^{106}$ Given the profound distrust for dissent and emphasis on conformity that characterized the 1950s, and in keeping with the careful precedent of promoting rather than defying American values set by the Civil Rights movement, Carville patients carefully and precisely marshaled beliefs about the home as representing "the center of freedom." 107 This tactic resonated in a context of mounting national efforts to end public housing projects—-depicted as "socialized housing" since the late 1940 s. ${ }^{108}$

For Gordon, who viewed Carville strictly as a hospital, the desire to cook for oneself remained unfathomable: "A lot of you seem to be of the opinion," he told the residents at a public meeting on the subject of cottages and cooking, "that if you are not living in a house [you] cannot get along too well.... The fact that you are married does not make it impossible for you not to live in a house on a hospital diet." A resident retorted, "If you had a chance to live in a home or a hotel room, in which would you live?" But Gordon, ignoring the question, persisted: "I do not understand why you cannot get along without a kitchen after you are married. I do not know what prevents you from eating in the dining room." The residents, in a discussion that was rapidly deteriorating into a shouting match with emotions running high and tempers flaring, tried to explain to the PHS officers that meals were not just at the center of life for the 17 married couples whose housing was most immediately threatened, but at the lives of all of the residents. Although they might also avail themselves of the cafeteria, all but the disabled cooked in their rooms and, "When anybody in Carville goes out to dine, he goes to somebody's house." ${ }^{109}$ The residents tried to convey the significance of their suburbs with the language of African American liberation: living in the cottages was "like being emancipated...."

Flatly rejecting the language of rights, Gordon countered that the patients "had no right to build" the cottages in the first place and no right to cook in their room. He condemned the liberality of previous MOCs: once you "condone and authorize things because you are sympathetic, first thing you know it becomes a right." The PHS was also concerned that private accommodations with a kitchen might encourage patient marriages, a custom tolerated but frowned on at Carville. Gordon reportedly jumped up at a public meeting and, pounding his fists on the table in a fit of rage, shouted: "For some strange reason you think because you are married you have to live in a private cottage and have your meals there. You married since you came here, you didn't come here married. Why do you think you have to have separate cottages and your food apart from the other patients?" 110 Gordon was not simply a petty tyrant bearing down on a group of vulnerable individuals. He was, rather, a man of science who held a very different vision of how the world at Carville—a hospital—should be organized. Domesticity may have represented a democratic ideal, but it had no place in the world of institutional politics.

No appeal would move Gordon: the cottages would come down and married couples would be transferred to apartments. He would make only one small concession: four couples could share a refrigerator to keep cokes or maybe small 
snacks cold. Although the refrigerator had become representative of middle class suburban attainment, the residents protested that this simply would not do. ${ }^{111}$ The MOC attempted to adopt the posture of a benevolent but stern patriarch scolding a child and replied that if they were "mature" about it they could manage. One thing was certain: "You will not be cooking in the apartment."112 The residents were equally adamant: "This is the last straw."113 Darryl Broussard, President of the Patient's Federation - a representative, elected body of the Carville population that had long handled residents' funds and had begun to serve as its formal political voice in 1932-declared that the situation had "reached the point ... where the patients have no confidence in or respect for the MOC." The Patient's Federation campaigned actively for Gordon's removal from Carville. ${ }^{114}$ For his part, Gordon dismissed the patient body: "There is nothing to the Federation." 115

In protest, the Federation cancelled all community activities. Although likely to be lost on an administration that did not recognize the residents as a community with rights, the refusal to participate in community life was a bold move equivalent to a sit-down. It was certainly influenced by the civil rights struggles over bus segregation taking place in nearby New Orleans and Shreveport beginning in 1956 and continuing into $1957 .{ }^{116}$ But it did not simply copy the efforts of Blacks: indeed, although a tactic first pioneered by labor earlier in the century and in northern cities by civil rights activists during the war, the sitin would not become a hallmark of the civil rights movement until the 1960 Greensboro lunch-counter sit-in. ${ }^{117}$ Carville was also swept up in the same social and political currents that made broader acts of civil disobedience possible. Said Broussard, "The cancellations will continue until they give us back what they took away from us." ${ }^{118}$ What had been taken was not simply housing, but the hard-earned domestic citizenship it represented: freedom from medical authority, patient privacy, and a degree of patient independence in daily routines.

Carville residents retained a lawyer and in August 1956 contacted their Congressman, Otto E. Passman, who came to talk to the boycotters and assess the situation for himself. Passman, a member of the House Appropriations Committee and the first US Congressman to visit Carville, sided with the residents, whom he regarded as citizens, taxpayers, and, now, voters deserving of the same rights and having the same legitimate desires as any of his constituents. ${ }^{119}$ Shortly after Passman returned to Washington, D.C., Dr. Gordon "requested" and was granted a transfer, though it was clear that the patients had forced the PHS to replace him. ${ }^{120}$ The ultimate success of the patient effort to regain their housing reflected the triumph of domesticity as a social and political ideology in the larger 1950s society.

In the post-Gordon era, while PHS officials continued to regard the idea of patient "cottages" with some incredulity and even condescension, there would be no more denying the residents interests in domestic privacy and certainly no denying them their kitchen-centered homes. While one officer continued to question whether the residents "really needed completely private accommodations including" not only kitchens but also baths, the PHS acknowledged that "the patients flatly rejected" Gordon's apartment plan with the shared refrigerator on the "grounds that they would be losing their privacy;" therefore, "no 
plan should be presented to the patients which in any way subtracts from their privacy." 121

Thus, the new plan, carried out between 1957 and 1960, provided for the destruction of all but one cottage-_Chateau Simon," a converted chicken coop that was nonetheless up to snuff in terms of electricity, plumbing, and infrastructural integrity - and the construction of 10 new fully apportioned detached brick cottages and one complex "with plush housekeeping apartments." "122 Together the units housed 22 married couples. ${ }^{123}$ (Figures 3 and 4.) The "push-button kitchen, built-in range and oven" was featured in a special edition of The Star documenting the triumphal return of residents to "a real home" in suburbia; and, of course, interviews with the proud new residents began in the kitchen. ${ }^{124}$

To be sure, the changes at Carville were influenced by many of the same factors that began to erode the stability of the notion that institutionalization was most appropriate for mental illness. As was the case with the sulfones, new therapies and successes with early intervention and treatment in community outpatient clinics in the post-war period were significant. These triumphs intersected with a decline in the Depression-era certainty that the State was responsible for social welfare and security and public exposes on the weaknesses of institutional care to bring an end to the era of institutionalization. ${ }^{125}$ But while we can understand the changes that took place at Carville in the post-war period as being of a piece with the larger movement toward deinstitutionalization that began to

\section{Figure 3}

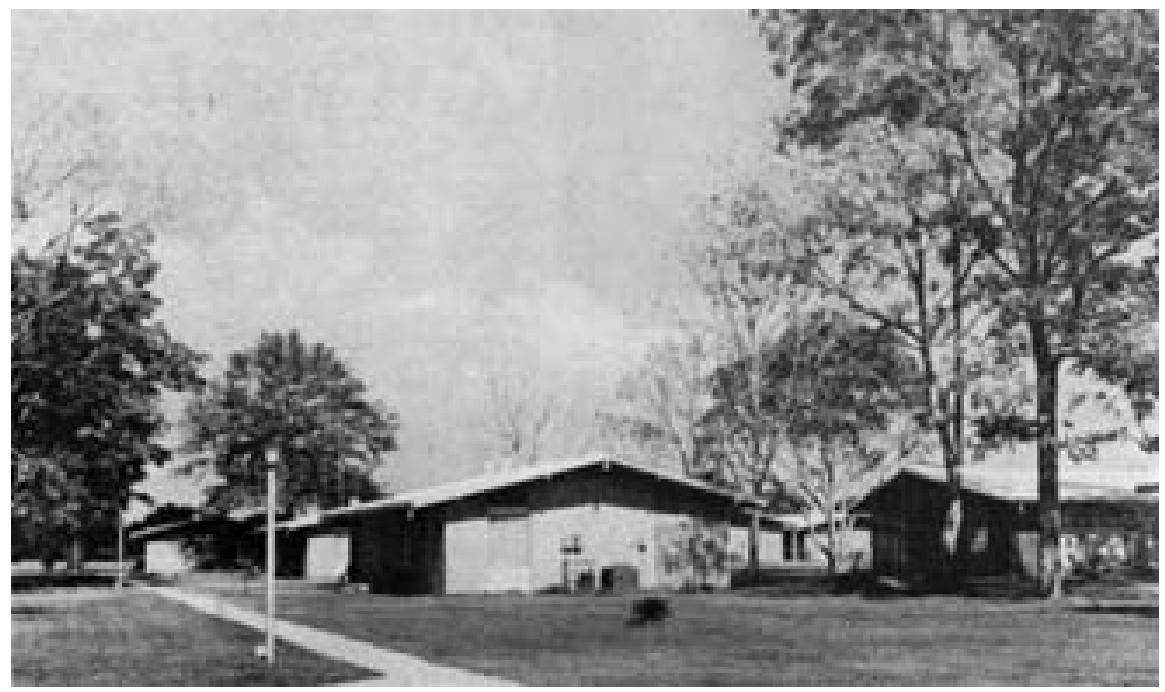

In the post-Gordon era, the PHS erected 10 new detached cottages for married couples in suburbia. Stanley Stein, The Star's bachelor editor was permitted to occupy the one old cottage allowed to remain standing. Source: The Star, Sept.-Oct. 1960, courtesy New York Academy of Medicine. 
Figure 4

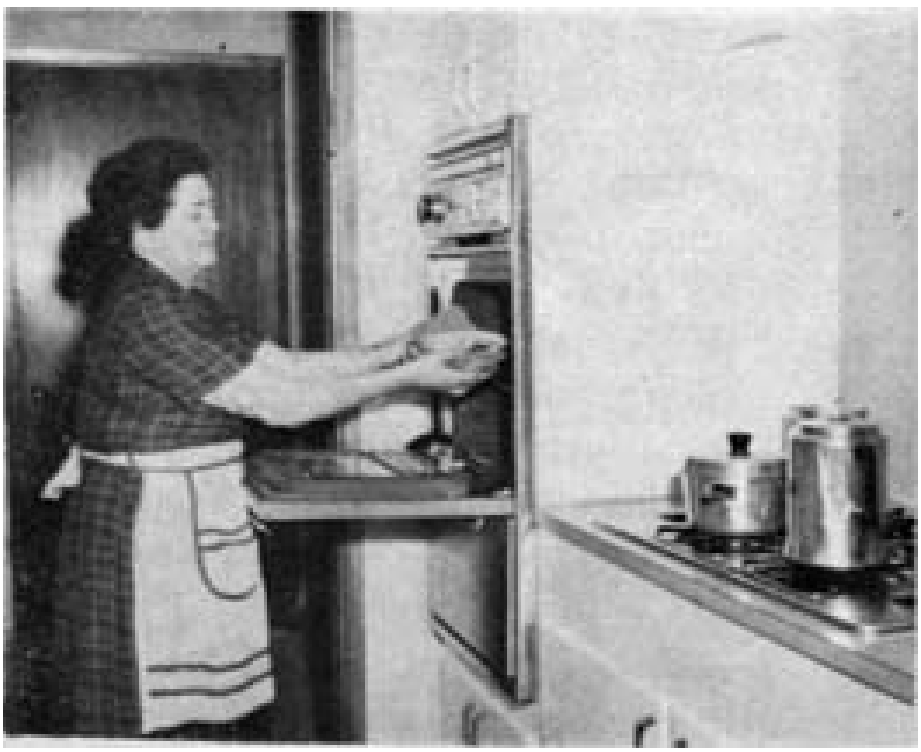

Each cottage in the new suburbia came complete with "push-button kitchen, built-in range and oven, central heat and air-conditioning and ultra-modern furnishings." Source: The Star, Sept.-Oct. 1960, courtesy New York Academy of Medicine.

gather steam in the 1950s and come to fruition in the 1960s and 1970s, Carville also stood apart from that movement. The goal at Carville had been to recreate the institution-to realize within its walls a broader set of social and cultural transformations-not to topple it.

\section{“Then there was the kitchen:” After Carville}

In the wake of the kitchen wars, The Star commented that the victory "comes at a strange time, when the hospital's patient census is at its lowest in many years." The right to maintain a private domestic life became far less consequential as more and more patients - both "old timers" and newly admitted cases_accepted medical discharge as the therapeutic promise of the early 1940s was fulfilled. ${ }^{126}$ Residents once again became patients to be treated and made comfortable.

In 1957 a new MOC, Dr. Edgar Bernard Johnwick, without raising any eyebrows announced that "The cottages will be assigned or reassigned to patients by the medical officer in charge in the same manner as other patients' living quarters.... The MOC, at his discretion, may terminate assignments to cottages and reassign the occupants to other quarters." Housing would be "dispensed" on 
a therapeutic basis. Decisions about whether a couple was healthy enough to carry on light housekeeping or whether husband and wife belonged in an apartment or even in separate dormitories were now strictly medical. Thus, while patients felt that they had thwarted administration plans to "make this hospital 'strictly institutional,' " the triumph in the kitchen battles coincided with the dawn of a new hospital era at Carville. ${ }^{127}$ In short, patients could no longer exercise their discretion about living accommodations, could not take the initiative to build cottages, and could no longer sell or rent their property. In part, patients accepted the new regime because they had already won what they wanted: the housing and an alternative institutional way of life. But as patients left, as Carville traveled in the direction of becoming just a hospital, the impetus for maintaining solidarity evaporated. Within Carville, then, the kitchen became just a kitchen — an accoutrement that made hospitalization more convenient and less burdensome but that had no implications for the patient's status as a rights-bearing citizen. ${ }^{128}$

On the outside, the kitchen would remain central to the former residents' conceptions of citizenship. In the early 1950s, for example, Betty and Harry Martin, after nearly two decades of confinement in Carville, were able to purchase their first small home with the proceeds from Betty's biography, an international bestseller. After describing the beautiful wooded property, Betty wrote in delight and even disbelief, "Then there was the kitchen. It was the only room we furnished completely right away, and I don't think any kitchen has ever been loved so much. I never come into it without a feeling of joy, and to us it is the heart of home and the source of health and much happiness." For Betty Martin, the kitchen remained a meaningful emblem of citizenship: "Only a person who has spent almost twenty years cooking furtive meals on a hot plate set on a window ledge could appreciate our well-furnished kitchen.... "129 Certainly their kitchen represented a luxury and convenience. But it also necessarily represented freedom from both State and scientific intrusion.

By the 1960s, while the Cold War intensified, the McCarthy era and limits on the ability to sharply critique America and its political ideology came to an end. As historian Mary Dudziak explains, "the civil rights movement took an important turn.... [It] was developing a broader base and was increasingly turning to the tactic of nonviolent civil disobedience." 130 The same social and political changes that enabled this shift in the civil rights movement also worked to subject the role of the physician as guardian of patient interests and privacy to challenge. By the early 1970s, patients' and women's rights advocates began to question medical paternalism as part and parcel of the broader challenge to physician authority and the emergence of a consumer rights movement. In 1969, for example, the Boston Women's Health Collective, in their enduring classic work of self-assertion, Our Bodies, Ourselves, sought to shatter the "myth" that doctor and patient "meet one another as parent and child." The women advised autonomy: "We want you to be more alert to our responsibility in the relationship, just as you would in any other adult relationship where you are purchasing services.... It's your body." ${ }^{31}$ As historian David Rothman explains, "The rules for patients had changed: docile obedience was to give way 
to wary consumerism." ${ }^{132}$ The forces that gave birth to such changes provided the context for and were in turn energized by the new bioethics, which had as its lodestar a commitment to patient autonomy and a rejection of medical paternalism.

A new kind of pride and celebration of identity and survival would become part and parcel the public experience of breast cancer, AIDS, multiple sclerosis, heart disease, and a variety of other chronic diseases or disabilities as people asserted control over their medical treatment and illness experience in the decades to follow. ${ }^{133}$ In this new climate, many subsequently discharged from Carville did so under their own names. It was not simply that they choose to expose themselves rather than to be exposed: they donned the mantel of activism and took on the challenge to change public discourse and social conditions. Those who left Carville not only identified as former Hansen's disease patients, but also began speaking about their experiences and the disease at social gatherings, churches, and service clubs and organizations. ${ }^{134}$

But the 1960s does not represent the dawn of the patients' rights era. Even if it represents its most dramatic and radical chapter, it is at best only a third. In comparison to the 1960s, patient protest was more conservative and constrained during the years of the Second World War and early cold war, but it nonetheless challenges us to push back the history of patient protest. The effort to democratize medicine and the institution was a critical precursor to efforts to achieve freedom from its authority.

Center for the History and Ethics of Public Health

Department of Sociomedical Sciences

Mailman School of Public Health

New York, NY 10032

\section{ENDNOTES}

1. Mary L. Dudziak, Cold War, Civil Rights: Race and the Image of American Democracy (Princeton and Oxford, 2000). Eric Foner, The Story of American Freedom (New York and London, 1998).

2. In 1894 Louisiana opened the "Leper Home" on the site of the abandoned "Indian Camp" sugar plantation near the town of Carville after citizens became aware of and began protesting the presence of the pest house and its seven "lepers." The state passed Carville off as an ostrich farm and smuggled the first patients 75 miles up the Mississippi by barge. One New Orleans doctor, who made regular visits, and four Sisters of Charity cared for the patients. The patients were housed in the plantation's old slave quarters while the Sisters occupied the decaying manor. It was, like most other southern institutions of confinement established during the nineteenth century, under-funded and physically inadequate. Gerald Grob, Mental Institutions in America: Social Policy to 1875 (New York and London, 1973), 359-69. In 1921 the PHS took command of the facility and, in this impoverished state dominated by the oil industry located deep in the heart of the segregated South, transformed it into the world's leader in leprosy research and treatment. Betty Martin, Miracle at Carville (Garden City, N.Y., 1950). 26-28. O.E. Denney, 
"The History of Leprosy in Louisiana," Public Health Reports 51 (1936): 1033. Herman E. Hasseltine, "History of Leprosy in the New England States," Public Health Reports 12 (1944): 69.

3. Carl F. Ameringer, State Medical Boards and the Politics of Public Protection (Baltimore, 1999), 14.

4. Marcia Gaudet, "Telling it Slant: Personal Narrative, Tall Tales, and the Reality of Leprosy," Western Folklore 49 (April, 1990): 193. In all states but New York leprosy was grounds for compulsory isolation at Carville.

5. In 1999, there were 108 known new cases in the US. http://www.cdc.gov/ncidod/dbmd/diseaseinfo/hansens_t.htm

6. Sheila Rothman describes institutions to house the tubercular as being "too prisonlike to be hospitals and too hospital-like to be prisons." Sheila M. Rothman, "The Sanitorium Experience: Myths and Realities," in The Tuberculosis Revival: Individual Rights and Social Obligations in a Time of AIDS (New York, 1992), 73.

7. "In the Old, Old, Days," The Star, Nov.-Dec 1954, 7.

8. The PHS, founded by Congress in 1798 as the United States Marine Hospital Service, was a uniformed service headed by the Surgeon General. Ralph Chester Williams, The United States Public Health Service, 1798-1950 (Washington, D.C., 1951). Gerald Markowitz and David Rosner, Deceit and Denial: The Deadly Politics of Industrial Pollution (Berkeley, 2002), 238.

9. Adam Fairclough, Race and Democracy: The Civil Rights Struggle in Louisiana, 19151972 (Athens, Georgia, 1995), 1-10. T. T. Lynn Smith and Homer L. Hitt, The People of Louisiana (1952). Arnold R. Hirsch and Joseph Logsdon, eds., Creole New Orleans: Race and Americanization (1992).

10. Martin, Miracle at Carville, p. 20; R.E, Pfaltzgraff, "What is the Actual Male/Female Sex Ratio on Leprosy Patients?" Leprosy Review 74;2(June 2003), 180-1; Thomas H. Rickman, Jr., Director, Community Activities, "The Little Red Schoolhouse is Growing Up," The Star (April 1950), p. 2.

11. Patients tended to select dorms based on their nationality.

12. Jim Duncan, "The South's Most Integrated Community," The Star, March-April 1965, 1-2. Michelle Moran, however, challenges the myth that Carville was essentially unsegregated. Instead, she argues, patients at Carville reified the hierarchies that prevailed in the broader society. Michelle Therese Moran, "Colonizing Leprosy: Imperialism, Patients, and the Politics of Public Health in Hawai'i and Louisiana" (Doctoral dissertation, University of Illinois at Urbana-Champaign, 2002). Beyond self-reports, however, there remains scant evidence regarding the degree to which peoples of different classes or cultures socialized within Carville. Those whose voices remain were certainly the most literate and influential within the institution. And, indeed, that suburban domesticity became of such paramount importance suggests that it may not have been simply isolation and protection from the PHS authorities that patients sought but perhaps a kind of segregation within the institution as well.

13. Ibid, $1-2$. 
14. Michael Worboys, "The Emergence of Tropical Medicine: A Study in the Establishment of a Scientific Specialty," in Perspectives on the Emergence of Scientific Disciplines, ed. Gerard Lemaine et al. (1976). W.M. Gibson, "Report of the President of the Board of Health to the Legislative Assembly on Leprosy," (Honolulu, 1886). Moran, "Colonizing Leprosy," 38-39. Nayan Shah notes that, in contrast to the American East and South, where "lepers" were white, it was also associated with the exotic and dangerous "Oriental" on Pacific Coast. Nayah Shah, Contagious Divides: Epidemics and Race in San Francisco's Chinatown (Berkeley, 2001), 99-100.

15. Centers for Disease Control and Prevention, "Leprosy," Morbidity and Mortality Weekly Report (December, 1999). The disease, which has an incubation period of several years, possibly a decade, appears to be spread via nasal droplets. Spread of the disease requires long-term contact with an infected person. There are two main types of the disease: lepramatous and tuberculoid. The attack rate for close household contacts for lepramatous leprosy is 6.2 cases per 1,000 persons per year; for the tuberculoid type, the attack rate is 1.6 per 1,000 . For non-household contacts, the attack rate is .8 per 1,000. James A. Doull, "The Epidemiology of Leprosy: Present Status and Problems," International Journal of Leprosy 30 (1962): 53. Leprosy is now typically cured with multiple drug therapy (some combination of rifampicin, clofazimine and dapsone) administered for six to 12 months, sometimes longer.

16. Linda K. Kerber, "The Meanings of Citizenship," The Journal of American History 84 (December, 1997): 836.

17. Alan Brinkley, Voices of Protest: Huey Long, Father Coughlin and The Great Depression (1982), 9. Ann Page, “Ann Page's The Ladies," The Star, April 1945, 15.

18. Stanley Stein and Lawrence Blockman, Alone No Longer (1963), 230-31.

19. John Parascandola, "Chaulmoogra Oil and the Treatment of Leprosy," Pharmacy in History 45 (2003): 47-57. John Parascandola, "Miracle at Carville: The Introduction of the Sulfones for the Treatment of Leprosy," Pharmacy in History 40 (1998): 59-66.

20. Erving Goffman, Asylums: Essays on the Social Situation of Mental Patients and Other Inmates (New York, 1961), 4-7.

21. Peter Applebone, "Leprosy Patients Recall a Pain Beyond Disease," New York Times, March 27 1989, A14. "Leprosy Victim Running Liquor Store Sought," Los Angeles Times, Jan. 29 1947, 4. The names of those very few brought in by force were, of course, known not only to the staff at Carville, but also to the public since the cases received a great deal of publicity. But for most, the "elaborate network of duplicity" extended not only to creating a false identity, but taking other measures to protect their identities: using post offices boxes to send mail to families, breaking off contact with families (sometimes voluntarily, sometimes not), renouncing disability and/or insurance benefits that would have provided financial assistance to the individuals confined or their families who remained outside. Martin, Miracle at Carville. 15.

22. Sidney Levyson initially resisted changing his name to Stanley Stein. But one of the Sisters of Charity who admitted him into Carville explained, "You must stop thinking of yourself. ... You have done nothing to be ashamed of, but there are some stupid people in the world and you must protect your loved ones from their stupidity.... Some patients 
have preferred that their friends believe them to be dead to save their families from abuse and ostracism. Choose a name you will be proud of some day." Stein, Alone No Longer, 37.

23. Martin, Miracle at Carville, 7 Stein and Blockman, Alone No Longer, 27-33.

24. Stein and Blockman, Alone No Longer, 27-28.

25. Martin, Miracle at Carville, 64. Stein and Blockman, Alone No Longer, 57-58.

26. Dolores Hayden, Building Suburbia: Green Fields and Urban Growth, 1820-2000 (New York, 2003), 97-120. Margaret Marsh, Surburban Lives (New Brunswick, 1990), 133. Alan Gowans, The Comfortable House: North American Suburban Architecture 1890 1930 (Cambridge, MA, and London, 1987), xiv.

27. The first prefabricated houses made available beginning in the late nineteenth century were precisely these types of structures. Gowans, The Comfortable House, 48.

28. Martin, Miracle at Carville, 75.

29. Martin Pernick, "The Patient's Role in Medical Decision Making: A Social History of Informed Consent in Medical Therapy," in Making Health Care Decisions (1982). Elizabeth Fee, Disease and Discovery: A History of the Johns Hopkins School of Hygiene and Public Health, 1916-1939 (Baltimore and London, 1987). Charles Rosenberg, "The Therapeutic Revolution," in The Therapeutic Revolution, ed. Morris Vogel and Charles Rosenberg (Philadelphia, 1979), 3-25. John Harley Warner, The Therapeutic Perspective: Medical Practice, Knowledge, and Identity in America, 1820-1885 (Cambridge, Mass, 1986).

30. Martin, Miracle at Carville, 75. John Parascandola, "An Exile in My Own Country: The Confinement of Leprosy Patients at the United States National Leprosarium," Medicina nei Secoli Arte e Scienza X (1998): 117. Parascandola, "Miracle at Carville: The Introduction of the Sulfones for the Treatment of Leprosy,"63.

31. Martin, Miracle at Carville, 187.

32. Frederick A. Johansen, "Recent Data on Promin Therapy," The Star, Sept 1947, 1. Robert Carlson, "Bayou Interlude," The Star, October 1947, 6. "TB Drugs Used to Treat HD," The Star, July-August 1950, 4. Gottfried Wozel, "The Story of Sulfones in Tropical Medicine and Dermatology," International Journal of Dermatology 28:29-30. Guy H. Faget and et al., "The Promin Treatment of Leprosy," Public Health Reports 58 (1943): 1729-41.

33. Guy Faget, "What Every Patient Should Know about Hansen's Disease," The Star, August 1942, 2,3. Guy Faget, "What the Patient Should Know about Hansen's Disease," The Star, February 1943, 5-6.

34. Harvey A. Levenstein, Revolution at the Table: The Transformation of the American Diet (New York and Oxford, 1988), 17, 21, 216 n.35.

35. Martin, Miracle at Carville, 38. "Voice of the Patients," The Star, May, 5. Stein and Blockman, Alone No Longer, 46, 60, 167. See also Johnny P. Harmon, King of the Microbes (Baton Rouge, 2000), Addendum 1, April 1999.

36. Susan Strasser, Never Done: A History of American Housework (New York, 1982), 48, 277. Levenstein, Revolution at the Table, 162, 208. 
37. Martin, Miracle at Carville, 21, 38, 40, 88. Harmon, King of the Microbes, 72. See also Strasser, Never Done.

38. Laura Shapiro, Perfection Salad: Women and Cooking at the Turn of the Century (New York, 1986), 212-15. Levenstein, Revolution at the Table. 61-62, 162-63, 169-171.

39. On the significance of gardens, see Strasser, Never Done, 28.

40. On the rise of domestic science or home economics, see Shapiro, Perfection Salad.

41. Faget, "What the Patient Should Know about Hansen's Disease," 6.

42. Stein and Blockman, Alone No Longer, 171. Kerber, "The Meanings of Citizenship," 833-854, Stein and Blockman, Alone No Longer, 171. Lizabeth Cohen, Making a New Deal: Industrial Workers in Chicago, 1919-1939 (Cambridge, England, 1990), 283-285. William E. Forbath, "Caste, Class, and Equal Citizenship," Michigan Law Review 98 (October, 1999): 1-91. Gowans, The Comfortable House, 8-9.

43. George Lipsitz, "The Meaning of Memory: Family, Class and Ethnicity in Early Network Television Programs," Cultural Anthropology 1 (November, 1986): 368.

44. Stein, Alone No Longer, p. 230-231; Foner, Story of American Freedom, pp. 221-247.

45. Samuel I. Rosenman (ed.) The Public Papers and Addresses of Franklin Delano Roosevelt, 13 volumes (New York, 1938-1950), IX, 672. See also Cass R. Sunstein, The Second Bill of Rights: FDR's Unfinished Revolution and Why We Need it More than Ever (Basic Books, 2004).

46. Eric Foner, Give Me Liberty! An American History (New York and London, 2005), 868.

47. Foner, Story of American Freedom, p. 223, 236-237.

48. Foner, Story of American Freedom, pp. 236, 240-241.

49. Betty Martin, "Americanism," December 1941, 7. Ann Page, "Personal Freedom," The Star 1942, 4. "Patients Polled on Promin," The Star, Dec 1945, 6.

50. Betty Martin, “Americanism,” The Star (December 1941):7.

51. Stein, Alone No Longer, p. 230-231.

52. Guy Faget, "What the Patient Should Know about Hansen's Disease," The Star, Dec 1942, 3. Faget, "What the Patient Should Know about Hansen's Disease," 5. The regulations were promulgated by the PHS in accordance with a Congressional Act passed Feb. 3, 1917, which required Carville to detain all persons reported by state health authorities. The regulations were approved by the Secretary of the Treasury on Dec. 4, 1922.

53. Stanley Stein, "Revise and Revoke," The Star, May 1943, 5. Guy Faget, "Rules and Regulations," The Star, April 1943, 2-3.

54. Marsh, Surburban Lives. Kenneth T. Jackson, Crabgrass Frontier: The Suburbanization of the United States (New York, 1985). 
55. Hayden, Building Suburbia, 128-53. Steven Mintz and Susan Kellogg, Domestic Revolutions: A Social History of American Family Life (New York, 1988), 183. For the significance of the "Comfortable House" as a symbol, realistically accessible to all, of democratic salvation for the nation and the world in the period prior to the Depression, see Gowans, The Comfortable House, xv, 11-12.

56. Foner, The Story of American Freedom, 264.

57. Lizabeth Cohen, A Consumer's Republic: The Politics of Mass Consumption in Postwar America (New York, 2003), 14, 112-13. Robert Fishman, Bourgeois Utopias: The Rise and Fall of Suburbia (New York, 1987), 15.

58. On the origins of suburbia as a device for merging town and country but also for separating home and family from work, middle class from working class, see Fishman, Bourgeois Utopias. See also Jackson, Crabgrass Frontier: The Suburbanization of the United States. Fishman (pp. 16-17) argues that as the suburbs became cities unto themselves in the post-war period, as they became "technoburbs," the founding vision and function of suburbia was lost.

59. Stein and Blockman, Alone No Longer, 46. Martin, Miracle at Carville, 47, 74, 75, 77.

60. Martin, Miracle at Carville, 241-45. Stanley Stein, "Reviewing Dr. Mosier's Article and Posing a Question," The Star, October 1944, 10. "Marriage-Carville Virsin [Sic]," The Star, June 1946, 16-17. Gertrude Hornbostel, "As I See It: After Two Years," The Star, June 1948, 4.

61. Peter Novick, The Holocaust in American Life (Boston and New York, 1999), 21-22. John W. Dower, War Without Mercy: Race and Power in the Pacific War (New York, 1986), 48 .

62. Howard A. Rusk, "Treatment of Leprosy Seen Based on Biblical Prejudice: 32 War Veterans at Carville, La., Hospital Complain of Status as Outcasts," New York Times, May 18 1947, 52. Gertrude C. Hornbostel, "Treatment for Leprosy: Care of Patients in Their Own State Favored Instead of Segregation," New York Times, November 18 1949, 28. Moran, "Colonizing Leprosy," 252, 282.

63. Dudziak, Cold War, Civil Rights. " "The Pancho Case-An Example," The Star, May 1948, 9-13. Amy L. Fairchild, "Community and Confinement: The Evolving Experience of Isolation for Leprosy in Carville, Louisiana," Public Health Reports 3 (May/June, 2004): 362-370.

64. "The Hornbostel Case," The Star, June 1947, 9-12, 17. Gertrude Hornbostle, "Rebuttal," The Star, October 1946, 12.

65. On the permeability of different spheres-political, economic, cultural, ideological - that helped to make citizenship more than a strictly political ideal, see Cohen, Consumer's Republic.

66. Page, "Ann Page's The Ladies," 15. Stanley Stein, "Past Progress-Future Goals," The Star, November-December 1944, 16. Stanley Stein, "Twenty Christmases in Carville," The Star, December 1950, 12. Martin, Miracle at Carville, 185. B. Jerris, "My Dormitory Room," The Star, February 1952, 10. 
67. Barbara M. Kelly, Expanding the American Dream: Building and Rebuilding Levittown (Albany, 1993), 65, 68, 217 n.91. Kelly, 68, writes, "The kitchen, a room that had previously been treated not only as private, but somewhat declassé, in most homes now shared the front of the house with the living room." See also Lipsitz, "Meaning of Memory," 36466. Marling, As Seen on TV: The Visual Culture of Everyday Life in the 1950s (Cambridge, MA, 1994), 249-50. Nancy Walker, "Humor and Gender Roles: The 'Funny' Feminism of the Post World War II Suburbs," American Quarterly 37 (Spring, 1985): 104, 105, 106. Harmon, King of the Microbes. 24, 73.

68. Harmon, King of the Microbes. 80-81.See also "Hornbostels Here to Buy New Home: Woman Cured in Leper Colony and Her Husband Arrive Somewhere on L.I.," New York Times, July 24 1949, 11. Ann Page, “Our Cottages,” The Star, 1947 February, 15.

69. Page, "Our Cottages," 14.

70. Shapiro, Perfection Salad, 212. "Strictly Human: Meet Melchor D. Santos," The Star, Nov.-Dec. 1957, 1. Stein, "Twenty Christmases in Carville," 12. Gertrude Hornbostel, "As I See It: After One Year," The Star, June 1947, 4. Martin, Miracle at Carville, 204. Although Carville inmates were self-described gourmands, the 1950s represented "the nadir of American cookery ... This was the Heyday of prepared foods and the cream-ofmushroom-soup school cuisine whereby the cook could pour a can of this product over anything that was not a dessert and create a culinary treat according to the standards of the day." Glenna Matthews, "Just a Housewife": The Rise and Fall of Domesticity in America (New York, 1987), 211. Laura Shapiro sees this phenomenon as part of a longer culinary decline that originated with turn-of-the-century domestic science, which emphasized form, efficiency, nutritional content, and presentation on the plate over the actual taste of food. Shapiro, Perfection Salad, 72, 83-84, 112.

71. Stein and Blockman, Alone No Longer, 202, 232.

72. Watson B. Miller, Memorandum, February 19, 1951, MS C 471 (Public Health Service Hospitals historical collection, History of Medicine Division, National Library of Medicine, Bethesda, Md.); "A Summary of the Recommendations of the Advisory Committee on Leprosy in the United States," The Star, January 1947, 9-10. For further discussion of the patient demands, see Fairchild, "Community and Confinement."

73. Fairchild, "Community and Confinement."

74. William G. Richardson, "Some Community Problems at the Carville US Marine Hospital," The Star, June 1947, 7-8. Richardson was the newly appointed Director of Community Services.

75. Stanley Stein, "Editorial: New Look at Hansen's Disease, Carville Fashion," The Star, October 1948, 8. "Hard Surfaced Road is Reality," The Star, May 1949, 6. Stein and Blockman, Alone No Longer, 239-244. It was the Louisiana State Legislature that granted patients the right to vote rather than the PHS administration. Major Hans Hornbostel, "Leprosy Was 'Fortunate’ for Wife, Major Thinks," Los Angeles Times, November 9 1947, 3.

76. Stein, "Revise and Revoke," 5, 6, Stanley Stein, "Carville's Bill of Wrongs," The Star, February 1944, 6. 
77. "Leprosy Expert to Retire After 29 Years at Hospital," New York Times, Leprosy Expert to Retire After 29 Years at Hospital 1953, 7. Betty Martin, No One Must Ever Know: The Struggle of Two Hansen Patients to Overcome the Stigma of Their Dreaded Disease in the Outside World (Garden City, N.Y.). 22-23. Stein and Blockman, Alone No Longer, 223-24. Moran, "Colonizing Leprosy," 283-84, 304-306.

78. Minutes of Meeting of Feb. 27, 1950, to discuss Public Health Service policy matters in connection with Leprosy; Letter from G.H. Hunt, Assistant Surgeon General, Associate Chief, Bureau of Medical Services, to Dr. Morris Greenberg, Director, Bureau of Preventable Diseases, New York City Health Department, New York, New York, July 16, 1952, MS C 471 (Public Health Service Hospitals historical collection, History of Medicine Division, National Library of Medicine, Bethesda, Md.); Thomas Parran, "To Combat Leprosy: Public Health Service plans Described by Surgeon General," New York Times, June 23 1947, 22. Gertrude C. Hornbostel, "A Misunderstood Disease: Enlightened Treatment Asked for Victims of Hansen's Disease," New York Times, August 16 1947, 12. Harry Nelson, "Leprosy Disease Called One of Least Infectious: Visiting Specialist Says It Now Can Be Controlled as Easily as Tuberculosis," Los Angeles Times, October 5 1960, B3. Parascandola, "An Exile in My Own Country: The Confinement of Leprosy Patients at the United States National Leprosarium,"121.

79. Quote in Foner, Give Me Liberty! An American History. 971.

80. "Crisis at Carville, to Be Resolved, We Hope," The Star, October-November 1956, 12.

81. Stein and Blockman, Alone No Longer. 308.

82. Stein, Alone No Longer, p. 305.

83. Alice Kessler-Harris, In Pursuit of Equity: Women, Men, and the Quest for Economic Citizenship in 20th-Century America (Oxford, 2001). Kessler-Harris also noted that economic citizenship included the right to the welfare benefits that were contingent on wage labor, though this dimension of economic citizenship had less relevance in this institutional context.

84. Ann Page, "My Black Onyx Dinner Ring," The Star, October 1955, 1. Stein and Blockman, Alone No Longer, 305. "There Have Been Some Changes Made," The Star, January 1955, 4.

85. Joanne Meyerowitz, "Beyond the Feminine Mystique: A Reassessment of Postwar Mass Culture," The Journal of American History 79 (1993):1471, 1474. Sara M. Evans, Born for Liberty: A History of Women in America (New York, 1997), 253-54.

86. "Ex-Aimee Aide to be Wed to Leper Sweetheart," Los Angeles Times, October 26 1947 , 1. Couples had to arrange furtive marriages, for the PHS did not allow them to marry at either the protestant or Catholic chapels on the facility grounds. Though many did "go through the hole" and get married on the outside, if they ever had to return they were placed in 30 days detention. Stein and Blockman, Alone No Longer, 51. After returning to Carville in 1939 after their unauthorized departure five years earlier, Harry and Betty Martin were punished. Harry spent 30 days in the Carville jail. Betty served her time in the "Doll House," a cottage reserved for mental patients. Martin, Miracle at Carville, 146. Henry R. Oliver, "Sixty Years of Psychiatry at Carville," Southern Medical 
Journal 80 (December, 1987): 1500. Alternatively, a couple might plan their vacations to coincide and then marry on the outside.

\section{Martin, Miracle at Carville, 119.}

88. In 1929 , Betty was paid $\$ 25$ a month to teach in Carville's integrated school. She quickly transferred to a more demanding job in the lab that paid $\$ 30$ a month. In the early to mid-1940s, her husband Harry earned $\$ 50$ a month as the head hospital patient orderly, the highest government salary a patient at Carville could earn. The job consisted of half a day of routine work and remaining on call 24 hours a day, which easily amounted to an eight hours a day, seven days a week. Ibid.34, 52, 198. As a point of comparison, the median family income in 1947 was \$296 a month and, in 1946, women working in a Navy Yard made 54 cents an hour (amounting to $\$ 121$ a month for an eight hour day, seven days a week), and their male counterparts earned 75 cents an hour ( $\$ 168$ a month). Median Family Income by Family Type, US, 1947-2001, Historical Income Tables-Families, US Census Bureau, US Department of Commerce, Housing and Household Economic Statistics Division, Income Surveys Branch. http://www.census.gov/hhes/income/histinc/ f07.html. Accessed August 2, 2004; Eugenia Kaledin, Mothers and More: American Women in the 1950s (Boston, 1984), 67.

89. Elaine Tyler May, Homeward Bound: American Families in the Cold War Era (New York, 1999), 14. Though they hold the Depression-era family up as less of an ideal, see also Mintz and Kellogg, Domestic Revolutions, 138-39. For an account of the possibilities that the Depression held for the interpenetration of domesticity and suburbia with implications for family structure, see Marsh, Surburban Lives.

90. To be sure, there was not a single family model that had roots in the Depression era. May, Homeward Bound, 30-48. Alice Kessler-Harris, Out to Work: A History of WageEarning Women in the United States, 20th Anniversary Edition ed. (New York, 2003), 254-56.

91. The degree to which work was divided along clear cut sex lines is a subject of some historical debate. While May and others, such as Nancy Walker and Mintz and Kellogg, suggest that the model of the male as primary wage earner was predominant, scholars like Joanne Meyerowitz, Alice Kessler-Harris, and Margaret Marsh argue that the cultural was not so monolithic, that not only did many families contain female bread-winners, but that accomplished women were widely admired and all were encouraged to be politically active as a means to combat Communism. Walker, for instance, suggests that men were only marginally involved in the maintenance of the household and, indeed, had to be cared for as a child would be cared for. Meyerowitz finds evidence that men did, in fact, provide significant help with housework. Without denying the broader cultural pressures for women to occupy the sphere of the home and men the sphere of the wage-earning world, Meyerowitz sees critical tensions and ambivalence in postwar discourse. There was no tension or ambivalence within Carville, perhaps because of the compromised position of men as potential wage earners. Marsh, Surburban Lives. Walker, "Humor and Gender Roles," 98-113. Kessler-Harris, Out to Work, 300-19. Mintz and Kellogg, Domestic Revolutions, 186-87. Meyerowitz, "Beyond the Feminine Mystique," 1455-82. Joanne Meyerowitz, "Introduction: Women and Gender in Postwar America, 1945-60," in Not June Cleaver: Women and Gender in Postwar America, 1945-1960, ed. Joanne Meyerowitz (Philadelphia, 1994), 4. Susan M. Hartmann, "Women's Employment and the Domestic 
Ideal in the Early Cold War Years," in Not June Cleaver: Women and Gender in Postwar America, 1945-1960, ed. Joanne Meyerowitz (Philadelphia, 1994), 84, 86, 89, 97. Evans, Born for Liberty, 252-53. Kaledin, Mothers and More, 24-41, 61-80. Hayden, Building Suburbia, 147.

\section{Martin, No One Must Ever Know, 30.}

93. George Lipsitz, Class and Cold War Culture in America: "A Rainbow at Midnight" (New York, 1981), 234-36. Lynn Y. Weiner, From Working Girl to Working Mother: The Female Labor Force in the United States, 1820-1980 (Chapel Hill and London, 1985), 89-91, 93-94, 112. Kaledin, Mothers and More, 61-65.

94. Stein and Blockman, Alone No Longer, 232. From 1894 through 1920, when Carville was run by the state, able-bodied patients were compelled to work as a means of covering the expense of their confinement. "It was a happy and exciting day," from the perspective of the inmates, "when this tiny world on the Mississippi was brightened by the national government taking over." Martin, Miracle at Carville, 29.

95. Martin, Miracle at Carville, 152, 198. Harmon, King of the Microbes, 77, 85. Kelly, Expanding the American Dream, 89. Mintz and Kellogg, Domestic Revolutions, 186-87.

96. Martin, No One Must Ever Know, 19.

97. Prior to Gordon, no one under the age of 12 could visit.

98. For equally practical reasons, couples were also likely to share the breadwinning after their discharge from Carville: a decade or two of institutional confinement for leprosy left one with no references, no usable past. Therefore, those who absconded or were discharged often became part of the working class. When Betty and Harry were medically released in 1946, for example, Betty sold stockings door to door when times were particularly hard (though her primary occupation was writing her memoir of Carville). Harry, a college-educated bookkeeper who had once owned and operated his own hardware store, was never able to gain employment doing anything except manual labor.

99. Hornbostel, “As I See It: After One Year," 4. Hornbostel, "Leprosy Was 'Fortunate' for Wife, Major Thinks," 3. Ann Page, "Our Cottages," The Star, February 1947, 15. "Strictly Human: Meet Melchor D. Santos," 1. Harmon, King of the Microbes, 86. See also Harmon's cafeteria cartoons, Addendum 1, April 1999.

100. "There Have Been Some Changes Made," 4.

101. "PHS Plan to Raze Cottages Raises Rumpus," The Star, October-November 1956, 7.

102. "Congressman Passman's Visit-Real Turning Point," The Star, October-November 1956, 3. "Senator Long Urges Consideration of Private Cottage Bill," The Star, February $1956,5$.

103. "Bad, Bad News for Carville Cottagers," The Star, July-August 1956, 16. R.T. Hollinger, "R.T. Hollinger, Legislative Legal Liaison Officer, to Dr. Hunt, Associate Chief, Bureau of Medical Services, Re: PHS Hospital, Carville, Patients' 'Private' Cottages, Oct. 22, 1953;" Memorandum from Chief, Social Service Branch, Division of Hospitals, to Chief, Division of Hospitals, Re. Carville, Aug. 23, 1956; Letter from Surgeon General to Senator Hennings, Aug. 28, 1956; Report on Meeting, March 17, 1958, MS C 471 
(Public Health Service Hospitals historical collection, History of Medicine Division, National Library of Medicine, Bethesda, Md.)

104. "PHS Plan to Raze Cottages Raises Rumpus," 7. Andrew Hurley, "From Hash House to Family Restaurant: The Transformation of the Diner and Post-World War II Consumer Culture," The Journal of American History 83 (March, 1997): 1288, 1294, 1297. Marling, As Seen on TV: The Visual Culture of Everyday Life in the 1950s, 153.

105. "PHS Plan to Raze Cottages Raises Rumpus," 7. Memorandum Re Carville from Chief, Division of Hospitals, to Chief, Social Service Branch, Division of Hospitals, Aug. 23, 1956 containing minutes of Meeting between Dr. Himmelsbach and patients interested in cottages, Aug. 2, 1956, MS C 471 (Public Health Service Hospitals historical collection, History of Medicine Division, National Library of Medicine, Bethesda, Md.)

106. Freedom of association, freedom of speech, and rights touching on freedom of choice in intellectual and spiritual matters are often privileged, regarded as absolutely fundamental to an open society. But as Robert McCloskey argues, the difficulty with this "formulation ... is that there is the smell of the lamp about it: it may reflect the tastes of the judges and dons who advance it, rather than the real preferences of the commonality of mortals." Robert McCloskey, "Economic Due Process and the Supreme Court: An Exhumation and Reburial," Supreme Court Review (1962): 34, 46. Much more mundane rights, like freedom of occupation, the ability to determine food purchases, or control over one's comfort and surroundings are likely far more important to most people on a day to day basis. Frank H. Easterbrook, "Implicit and Explicit Rights of Association," Harvard Journal of Law and Public Policy (1962): 91, 98. See also Lawrence Tribe, American Constitutional Law, 2nd ed. (1988), 1373-1374. Janet Franz, who has analyzed the politics of the efforts to close the facility, refers to these as "normative" rights. Janet E. Frantz, "Political Resources for Policy Terminators," Policy Studies Journal 30 (2002): 24.

107. Dudziak, Cold War, Civil Rights, Hayden, Building Suburbia, 130-31, 148.

108. Kelly, Expanding the American Dream, 60-63. May, Homeward Bound, xxv. Foner, The Story of American Freedom, 257, 264, 266. Hayden, Building Suburbia. 130-31.

109. Memorandum Re Carville from Chief, Division of Hospitals, to Chief, Social Service Branch, Division of Hospitals, Aug. 23, 1956 containing minutes of Meeting between Dr. Himmelsbach and patients interested in cottages, Aug. 2, 1956, MS C 471 (Public Health Service Hospitals historical collection, History of Medicine Division, National Library of Medicine, Bethesda, Md.); Stein, Alone No Longer, 60, 168; Martin, Miracle at Carville, 151, 204.

110. Memorandum Re Carville from Chief, Division of Hospitals, to Chief, Social Service Branch, Division of Hospitals, Aug. 23, 1956 containing minutes of Meeting between Dr. Himmelsbach and patients interested in cottages, Aug. 2, 1956 and Memorandum on Meeting held in Dr. Nelson's office, March 11, 1958, at 1:30 p.m. to discuss the arrangements for housing patients at Carville, March 17, 1958, p. 6., MS C 471 (Public Health Service Hospitals historical collection, History of Medicine Division, National Library of Medicine, Bethesda, Md.); "PHS Plan to Raze Cottages Raises Rumpus," 7. Notably this exposé was published after the announcement that Gordon was departing.

111. Strasser, Never Done, 266-67. 
112. Memorandum Re Carville from Chief, Division of Hospitals, to Chief, Social Service Branch, Division of Hospitals, Aug. 23, 1956 containing minutes of Meeting between Dr. Himmelsbach and patients interested in cottages, Aug. 2, 1956, MS C 471 (Public Health Service Hospitals historical collection, History of Medicine Division, National Library of Medicine, Bethesda, Md.)

113. "Bad, Bad News for Carville Cottagers," 16. Transcripts of interviews with Sister Frances DeSales, pp. 4-5, Sam and Theresa, pp. 6-7, and Pete Peterson, p. 2, Secret People Film Project.

114. Stein and Blockman, Alone No Longer, 130. Ed Clinton, "Patients' Federation Hub of Hospital Life," Baton Rouge State-Times Aug. 22, 1956, MS C 471 (Public Health Service Hospitals historical collection, History of Medicine Division, National Library of Medicine, Bethesda, Md).

115. "Congressman Passman's Visit-Real Turning Point," 9.

116. Fairclough, Race and Democracy, 210-16.

117. Foner, Give Me Liberty! An American History, 980.

118. "Patients Cancel Activities," The Star, October-November 1956, 10.

119. “Congressman Passman’s Visit-Real Turning Point," 9.

120. Parascandola, “An Exile in My Own Country: The Confinement of Leprosy Patients at the United States National Leprosarium,"121.

121. Memorandum on Meeting held in Dr. Nelson's office, March 11, 1958, at 1:30 p.m. to discuss the arrangements for housing patients at Carville, March 17, 1958, p. 1. Public Health Service Hospitals historical collection, MS C 471 (Public Health Service Hospitals historical collection, History of Medicine Division, National Library of Medicine, Bethesda, Md.); Amy L. Fairchild, "The Democratization of Privacy: Public Health Surveillance Changing Conceptions of Privacy in the Twentieth Century," in Health Care History and Policy in the United States, ed. Rosemary A. Stevens, Charles E. Rosenberg, and Lawton R. Burns (Piscataway, NJ, 2006).

122. The PHS survey of the cottages revealed that many of them were poorly constructed and wholly inadequate in terms of basic sanitation. The MOC who followed Gordon, though entirely supportive of providing residents with "better housekeeping quarters" felt that renovation of the cottages would be "like pouring money down a rat hole." "Carville on the Go: New Building Program and Other Improvements Set $\$ 90,000$ for Research," The Star 1958, 12. On plumbing, see Strasser, Never Done, 100.

123. In the post-Gordon era "bachelors" of neither sex were neglected, but suburbia was reserved for married couples. Singles were given "hotel-like" accommodations, the central feature of which was a private bath; there were no kitchens. "Lights and Laughter In Cottage Grove Again: Now Called Suburbia,” The Star, August-September 1960, 13. May, Homeward Bound, xxiii.

124. "Lights and Laughter In Cottage Grove Again: Now Called Suburbia," 12, "Housing Transformation at Carville," The Star, November-December 1960, , "Memorandum on Meeting held in Dr. Nelson's office, March 11, 1958, at 1:30 p.m. to discuss the arrange- 
ments for housing patients at Carville, March 17, 1958. Public Health Service Hospitals historical collection, MS C 471.”

125. Gerald N. Grob, From Asylum to Community: Mental Health Policy in Modern America (New Jersey, 1991), 4, 5-23, 70. "Housing Transformation at Carville," 11.

126. "Carville on the Go: New Building Program and Other Improvements Set $\$ 90,000$ for Research," 12. Martin, No One Must Ever Know, 29.

127. "Uncle Sam Takes Title to Cottages," The Star, July-August 1958, 4. But it was also much more of a hospital and less of a "total" institution. For example, patients were allowed to have cars, take courses, and come and go from Carville freely. Therefore, the time spent within Carville tended to be limited to treatment. Patients, who typically responded to treatment within a few months and expected to be discharged within two to three years, remained far more connected with their communities and families on the outside. Fairchild, "Community and Confinement,"368-69.

128. Frank A. Brown, "Carville-As Seen by an Ex-Patient," The Star, June 1956, 6. Transcript of interview with Julia Elwood, Secret People Film Project, pp. 5-6, 16. Patients accepted the new policy not only because it came at a moment of change at Carville, when more and more patients were being discharged and the community was fragmenting, but also because the new MOC acknowledged and included them in decision-making. Upon arrival at Carville, Johnwick immediately called a general meeting of staff, medical officers, and patients. Carville's goals, he explained, would on be accomplished by "a team that is made up of the staff and patients." Further, Johnwick made clear that the policies of the Gordon administration would not stand: "No one should be discharged from this hospital against his will. No one should be kept in this hospital against his will." "MOC Creates Favorable First Impression," The Star, November-December 1956, 7 .

129. Martin, Miracle at Carville, 292. Martin, No One Must Ever Know, 173-74. Other former residents of Carville also but less famously and described their search for a home. Ann Page, "It's the Discharge Road for Me," The Star, October-November 1956, 5. Harmon, King of the Microbes, 111.

130. Dudziak, Cold War, Civil Rights, 157.

131. Boston Women's Health Collective, Our Bodies, Ourselves (Boston, 1969), 253.

132. David J. Rothman, Strangers at the Bedside: A History of How Law and Bioethics Transformed Medical Decision Making (New York, 1991), 144.

133. Amy L. Fairchild, "The Polio Narratives: Dialogues with FDR," Bulletin of the History of Medicine (Fall, 2001): 488-534. Fairchild, "Democratization of Privacy."

134. Gertrude Hornbostle, "The Truth Shall Set you Free," The Star, February 1949, 3. Brown, "Carville-As Seen by an Ex-Patient," 7. "Bataan Hero Discharged in Record Time," The Star, June 1951, 5. Ann Page, "A Rewarding Experience," The Star, October 1950, 3. Nancy E. Waxler, "Learning to be a Leper: A Case Study in the Social Construction of Illness," in Social Contexts of Health, Illness and Patient Care, ed. E.G. Mishler (Cambridge, England, 1981), 170, 182-83. "Leprosy Halted, Happy Veteran Speeds to LA," Los Angeles Times, May 29 1951, 2. "Joey Again Faces Test of Courage," The Star, November-December 1960, 4. 